\title{
KOMUNITARIAN MASYARAKAT NELAYAN INDONESIA: KAWASAN PESISIR RUPAT UTARA
}

\author{
Geovani Meiwanda, Nur Laila Meilani, dan Khairul Amri \\ FISIP Universitas Riau, Kampus Bina Widya Km. 12,5 Simpang Baru Panam, Pekanbaru 28293
}

\begin{abstract}
The coastal area of Riau Province is directly facing the Straits of Malacca, the northern part of the Rupat Island coastal area. northern rupat is famous for tourism, through the beautiful white sand beach. An interesting problematic of this paper is that the fishing communities who are always in the data become poor communities. sea and fishermen have been partners for a long time, have formed communities but these communities do not provide welfare. The focus of research in this article is in the villages of Tanjung Medang, Teluk Rhu Village and also Tanjung Punak Village. These three villages are the northernmost villages with a coastline, and fishing households are domiciled in this area. these villages have fishing communities and several joint small business groups (KUBE). by using qualitative research methods, supported by secondary data and primary data. this article describes the successes and challenges of fishing village communities in marine products. Through the concept of Communitarian by Etzioni, this writer describes the reality of the concept of subsidies that occur in fishing communities in villages that are locus, and the presence of the state in supporting the welfare of coastal communities.
\end{abstract}

\begin{abstract}
Abstrak: Wilayah pesisir Provinsi Riau berhadapan langsung dengan Selat Malaka, bagian utara wilayah pesisir Pulau Rupat. rupat utara terkenal akan pariwisata, melalui pantai pasir putih yang indah. Masalah yang menarik dari makalah ini adalah bahwa komunitas nelayan yang selalu dalam data menjadi komunitas miskin. laut dan nelayan telah menjadi mitra sejak lama, telah membentuk komunitas tetapi komunitas ini tidak memberikan kesejahteraan. Fokus penelitian dalam artikel ini adalah di desa Tanjung Medang, Desa Teluk Rhu dan juga Desa Tanjung Punak. Ketiga desa ini adalah desa paling utara dengan garis pantai, dan rumah tangga nelayan berdomisili di daerah ini. desa-desa ini memiliki komunitas nelayan dan beberapa kelompok usaha kecil bersama (KUBE). dengan menggunakan metode penelitian kualitatif, didukung oleh data sekunder dan data primer. artikel ini menjelaskan keberhasilan dan tantangan masyarakat desa nelayan dalam produk laut. Melalui konsep Communitarian oleh Etzioni, penulis ini menggambarkan realitas konsep subsidi yang terjadi pada masyarakat nelayan di desa-desa yang bersifat lokus, dan kehadiran negara dalam mendukung kesejahteraan masyarakat pesisir.
\end{abstract}

Kata Kunci: komunitarian, wilayah pesisir, kesejahteraan, komunitas pesisir

\section{PENDAHULUAN}

Pembangunan yang dilakukan diharapkan berdampak positif pada kesejahteraan masyarakat dalam bentuk penguatan ekonomi masyarakat. Prioritas kebijakan pembangunan dalam menguatkan perekonomian masyarakat di daerah 3T ini sagat penting dilakukan, karena pembangunan yang dilakukan di daerah $3 \mathrm{~T}$ khususnya di Pulau Rupat Kabupaten Bengkalis belum sepenuhnya berdampak pada penguatan ekonomi masyarakat lokal. Padahal pemerintah sudah banyak mengucurkan kebijakan dalam bentuk program-program untukmembangun Pulau Rupat, baik program pembangunan infrastruktur, 109110 maupun pembangunan dalam bentuk program-program, seperti UED/ K-SP, PNPM, INBUP, PPD, dan ADD.
Upaya Kabupaten Bengkalis untuk menjadi kabupaten yang mampu memberikan kesejahteraan bagi masyarakat salah satunya wilayah pesisir. Gerbang Pesisir menjadi salah satu fokus pembagian zonasi pembangunan di Kabupaten Bengkalis. Pulau Rupat merupakan bagian dari Kabupaten Bengkalis yang menjadi zona wilayah Pesisir yang sebelah utaranya langsung berhadapan dengan Selat Malaka. Bengkalis merupakan salah satu Kabupaten di Propinsi Riau yang memiliki posisi strategis dalam pengembangan pariwisata pantai karena berhadapan langsung dengan pelayaran internasional, yaitu Selat Malaka dan berada dalam kawasan segitiga pertumbuhan, yakni segitiga pertumbuhan Indonesia-Malaysia-Singapura dan Indonesia-Malaysia- 
Thailand (Indonesian Ecotourism Network, 2002). Potensi lain yang tidak kalah menarik adalah potensi sumber daya lokal yang ada di Kabupaten Bengkalis.

Tahun 2016 lalu Pemerintah Provinsi Riau dan Kabupaten Bengkalis fokus untuk menjadikan Pulau Rupat sebagai pusat pariwisata unggulan daerah, perkebunan, peternakan, kelautan dan perikanan. Dari uraian visi dan misi Kabupaten Bengkalis di atas, terlihat jelas bahwa Pemerintah Kabupaten Bengkalis menjadikan Pulau Rupat sebagai pusat kegiatan pembangunan, yakni sebagai Gerbang Pesisir, yang fokus pembangunannya adalah pada pariwisata unggulan daerah, perkebunan, peternakan, kelautan dan perikanan.

Pulau Rupat pada Kecamatan Rupat Utara saat ini, destinasi pengembangan aspek roda ekonomi masyarakat, menjadikan Pulau Rupat bagian Utara sebagai destinasi wisata dengan menjual wisata pantainya yang putih dan berbisik dalam satu Kawasan Pariwisata Strategi Nasasional (KPSN). Lewat berkembang pesatnya Rupat Utara menjadi kawasan wisata. Potensi besar terbungkus rapi dikawasan Pulau Rupat Utara, yang perlu diperhatikan oleh Pemerintah Lokal khususnya. Wilayah pesisir yang merupakan wilayah yang kaya akan potensi kelautan, dan keindahan alamnya. Potensi yang selama ini perlu campur tangan besar antara masyarakat itu sendiri, pemerintah dan pihak ketiga. Sektor perikanan merupakan satu hal yang sangat besar disana namun tidak memiliki nilai yang besar untuk masyarakat.

Sumber daya perikanan dari hasil laut pesisir Rupat adalah salah satu asset bagi masyarakat dan masyarakat nelayan khususnya yang pengelolaannya secara optimal haruslah memerlukan pendekatan pembangunan berkelanjutan (sustainable development). Oleh karena itu, kita mesti mengetahui secara nyata kondisi dari pada sumberdaya perikanan laut secara keseluruhan, agar dalam pengembangan dan pengelolaannya dapat lebih optimal. Perbandingan kondisi sumberdaya perikanan laut untuk ke tiga Zona tangkap di perairan Kabupaten Bengkalis.

Fenomena yang terjadi saat ini konsepsi masyarakat yang demikian tersebut, perlahan namun pasti telah mengalami perubahan signifikan, kearah model masyarakat liberalisme yang mengedepankan aspek kompetisi, liberalisasi, dan unsur partisipasi. Ketiga unsur tersebut melahirkan sebuah paradigma individualitas yang menjadi orientasi utama. Individualitas menjadi sebuah konsekuensi logis atas kebijakan publik yang lebih mengedepankan unsur demokrasi liberal. Sebenarnya dalam demokrasi sebagai sebuah sistem kehidupan yang saat ini menjadi alternatif terbaik, dari sistem yang lain yang tersedia. Mampu diwujudkan dalam 2 tataran pokok; prosedural (struktural), dan kultural. Prosedural terkait dengan penentuan kebijakan publik, proses penentuan kepemimpinan, dan aktualisasi kepentingan masyarakat. Sedangkan dari aspek kultural, sangat dipengaruhi oleh budaya masyarakat setempat. Dimana kondisi masyarakat yang multikultural, menjadi modal dalam penerapan tipe demokrasi yang bersifat kultural.

Melemahnya kekuatan dan fungsi tujuan dari komunitas dalam mengelola sumber daya lokal di Pulau Rupat menyebabkan beberapa dampak khususnya ekonomi masyarakat secara signifikat. Masyarakat mengetahui bahwa potensi perikanan dalam laut yang sangat dekat dengan mereka, tidak memiliki nilai yang maksimal. Kecendrungan sumber daya lokal yang dimiliki dan didapatkan oleh masyarakat saat ini memiliki nilai jual yang sangat rendah, tidak sesuai dengan harga pasar. Situasional tersebut berbanding terbalik dengan keberadaan Pulau Rupat sebagai kawasan yang memiliki potensi pengembangan pariwisata yang digadanggadang dengan tagline yang besar.

Pulau Rupat di kawasan Kecamatan Rupat Utara merupakan wilayah dengan sejuta pesona yang dimiliki. Pesona keindahan alam, kekayaan hasil sumber daya alam dari laut maupun darat, hingga keunikan adat istiadat yang tumbuh di masyarakat. Bagian paling ujung di Pulau Rupat, ternyata tidak hanya memberikan manfaat yang seharusnya diakhir manfaat akan memberikan nilai ekonomis yang tinggi bagi masyarakat. Salah satu bentuk manfaat dari Kecamatan Rupat Utara yang menjadi lokus 
dalam penelitian ini yaitu Desa Tanjung Punak dan Desa Teluk Rhu. Dua desa yang bertetangga dalam Kecamatan Rupat Utara sebagian masyarakatnya menggantungkan hidup dengan bermata pencaharian sebagai nelayan.

Secara geografis Rupat Utara merupakan wilayah Riau Pesisir yang langsung menghadap ke Samudera Hindia, dan langsung berhadapan dengan negara tetangga Malaysia. Perairan besar laut lepas tentu banyak kapal asing yang melintasi wilayah tersebut, terlihat bahwa situasi tersebut akan memberikan keuntungan bagi masyarakat dan juga negara Indonesia. Namun sama halnya dengan fenomena-fenomena wilayah hampir terluar Indonesia lainya, harapan dan keuntungan tidak sesuai dengan kenyataan yang terjadi. berikut tabel sebaran wilayah di Kecamatan Rupat Utara.

Tabel 1. Luas Wilayah Rupat Utara menurut Desa/Kelurahan

\begin{tabular}{|c|c|c|}
\hline Desa/Kelurahan & $\begin{array}{c}\text { Luas Wilayah } \\
\left(\mathrm{Km}^{2}\right)\end{array}$ & $\%$ \\
\hline 1. Titi Akar & 185 & 29,46 \\
\hline 2. Tanjung Medang & 66 & 10,51 \\
\hline 3. Teluk Rhu & 72 & 11,46 \\
\hline 4. Tanjung Punak & 73 & 11,62 \\
\hline 5. Kadur & 52 & 8,38 \\
\hline 6. Hutan Ayu & 57 & 9,08 \\
\hline 7. Suka Damai & 58 & 9,24 \\
\hline 8. Putri Sembilan & 65 & 10,35 \\
\hline
\end{tabular}

Sumber: BPS Kabupaten Bengkalis, 2017

Delapan desa yang menjadi wilayah administratif dari Kecamatan Rupat Utara, dengan Desa Tanjung Medang yang menjadi ibu kota dari Kecamatan Rupat Utara. Tanjung Medang yang menjadi pusat di Kecamatan, pelabuhan kecil untuk akses keluar masuk juga terdapat di Desa Tanjung Medang serta tempat pengepul ikan dari nelayan-nelayan sepanjang pesisir Rupat Utara juga berada di Desa Tanjung Medang.

Desa Tanjung Punak dan Desa Teluk Rhu salah satu desa yang masyarakatnya mengelola dan langsung menjadi nelayan sejak turun menurun, dan dahulu kerap melakukan transaksi jual beli kepada kapal-kapal asing yang melintasi. Jumlah rumah tangga perikanan di Desa Teluk Rhu terdapat 321 rumah tangga perikanan (RTP). Wilayah pesisir Selain hal tersebut
Nelayan Rupat Utara mendapat perhatian serius dari pemerintah pusat maupun dari pemerintah daerah, dalam hal kesejahteraan dari nelayan juga tidak lepas dari penyelamatan lingkungan dan berbagai alat tangkap dan fasilitasnya.

Keadaan dan ekonomi tidak lepas pula menjadi problematikan bagi masyarakat setempat. Keadaan ini akan diperburuk lagi dengan adanya penduduk miskin. Untuk sekedar mempertahankan hidupnya, penduduk miskin seringkali terpaksa mengeksploitasi sumberdaya alam, baik yang dalam penguasaannya maupun milik bersama (common property, common resources) yang mengakibatkan degradasi sumberdaya alam dan lingkungannya.

Menurut pandangan komunitarian, inti negara kesejahteraan yang kuat, tetapi terbatas harus dipertahankan. Tugas-tugas lain yang selama ini dilaksanakan negara harus diserahkan kepada individu, keluarga dan komunitas. Menerapkan prinsip subsidiary. Prinsip ini menyatakan bahwa tanggung jawab untuk setiap situasi pertama-tama jatuh pada mereka yang paling dekat dengan persoalan. Hanya ketika solusinya tidak bisa ditemukan oleh individu, maka keluarga harus ikut terlibat. Jika keluarga tidak bisa mengatasinya, barulah komunitas lokal boleh terlibat. Jika memang persoalannya terlalu besar untuk komunitas, barulah negara diperbolehkan terlibat (Parsons, 2005).

Dalam Atno Anzenbacher Komunitarisme mengajukan beberapa catatan kritis atas pandangan kaum liberal, beberapa point penting kritikan kaum komunitarian tersebut adalah: Pertama, kaum komunitarian menolak konsep antropologi liberal yang melihat manusia sebagai unencumbered self ${ }^{\star}$ atau manusia tanpa komunitas. Manusia dalam pandangan kaum liberal dimengerri sebagai individu yang terisolir dan melayang-layang di ruang kosong serta ditempatkan dalam ruang-ruang hak kebebasan. Dalam kenyataanya, manusia selalu hidup dalam komunitas, tradisi dan ikatan sosial. Sebuah sistem sosial yang tidak menggubris aspek-aspek sosial ini dan hanya membatasi diri pada pemahaman tentang manusia sebagai pribadi hukum dalam ruang-ruang kebebasan, menghancurkan substansi sosial 
hidup manusia dan cenderung menghantar masyarakat kepada bahaya individualisasi, atomisasi dan penghancuran nilai solidaritas. bahaya atomisasi sosial dan melemahnya solidaritas dipertajam lagi dengan dominasi imperatif ekonomi. Rationalitas ekonomi pasar terus mengikis dan memarjinalisasi dimensi etis, kultural dan religius bersama tradisi dan komunitaskomunitasnya (agama misalnya).

Kedua, solusi apa yang ditawarkan kaum komunitarian untuk mengatasi bahaya individualisasi, ekonomisasi dan desolidarisasi (entsolidarisierunf)? Solusi kaum komunitarian ialah dengan menawarkan dan memperkuat komunitas-kominitas, kelompok-kelompok dan trdisi komunitarian dimana manusia dapat mengalami, mempratikkan dan mengintemalisasi identitas kultural, etos sosial, solidaritas dan maknabersama. Komunitarismemenawarkan solusi dengan mengikat kembali "unencumbered self" kedalam keluarga, sanak saudara, tetangga, komunitas agama, jaringan sosial dan segala macam persekutuan sosial sampai akhirnya identitas sosial bangsa yang mam pu memberikan makna hidup. Keutamaan etis untuk melawan egoisme ekonomis hanya mungkin dikembangkan melalui proses integrasi ke dalam komunitas dan tradisi komunitarian. Tanpa sikap-sikap yang dihayati dan ditradisikan secara komunitarian, sebuah masyarakat akan mengalami degradasi menjadi semata onggokan (Hatfe n -Txylot) pribadi juridis yang tak berdaya di hadapan "despotism administrative" (BeUab), yang kemudian berakhirpadaindividualism ebirokratis(Macintyre) dan kebingungan publik yang tanpa arah (Barber).

Charles Taylor dalam Sources of the Self berpendapat bahwa modernitas dalam wajah liberal telah melupakan akar, substansi dan sumber kehidupannya. Akar dan sumber mata air kehidupan moderen dan juga sumber bagi subjek bebas atas dasar faham hak-hak asasi manusia bersifat pandangan hidup, religius dan metafisis. Hanya modernitas yang merefleksikan sumber kehidupannya dan membaharui lewat proses refleksi tersebut dapat menjadi pengawal dan pembela kebebasan dan martabat manusia. Mengeringnya sumber mata air modernitas tersebut jelas menggoncangkan basis legitimasi bangunan kultural moderen. Karena itu keadilan dan hukum berpijak pada konsep hidup baik dan mengandaikan konsep hidup baik. Tanpa pilihan makna dan nilai hidup baik yang dihayati serta berpijak pada tradisi etis-religius dan ideologis, sistem hukum moderen (hak dan keadilan) akan remuk seketika.

Gerry van Klinken menyebut munculnya politik komunitarian dalam konteks otonomi daerah dan desentralisasi pasca-Soeharto, tetapi amatan dia tertuju secara terbatas pada kebangkitan keraton-keraton lokal. Vedi Hadiz dan Robert Hefner, mengaitkan beberapa gagasan dan aksi politik Indonesia dengan komunitarianisme sebagaimana diperdebatkan dalam filsafat dan teori politik, meskipun analisis awal mereka berangkat dari pembahasan tentang kontras antara demokrasi Barat dan demokrasi berbasis 'Asian values' - secara sinis sering disebut 'illiberal democracy' yang menjadi kerangka umum dalam buku bunga-rampai suntingan Chua Beng Huat itu.

John Locke berpendapat bahwa kebebasan yang menjadi nilai dasar liberalisme dipahami sebagai ketidakhadiran intervensi eksternal dalam aktivitasaktivitas individu. Kebebasan adalah hak properti privat. Karenanya, pemerintah bersifat terbatas (minimal) terhadap kehidupan warganya. Untuk itu harus ada aturan hukum yang jelas dan lengkap dalam menjamin kebebasan sebagai hak properti privat ini.

Rousseau berpendapat bahwa pemerintah harus tetap berfungsi menjamin terlaksananya kebebasan individu dalam masyarakat Mac Intyre mengatakan bahwa dalam memutuskan bagaimana menjalankan kehidupannya, "semua mendekati keadaan sekitar dirinya sendiri sebagai pembawa identitas sosial tertentu. Apa yang baik bagi saya harus juga baik bagi orang-orang yang menduduki peranan-peranan ini" Karenanya, penentuan diri sendiri dan pilihan-pilihan tentang hidup yang baik dilakukan dalam berbagai peranan sosial ini.

Menurut Taylor, nilai individualisme liberal bersifat atomistik, yang menganggap 
individu bisa mencukupi diri mereka sendiri di luar masyarakat. Individu menurut liberalisme tidak memerlukan konteks komunitas untuk mengembangkan dan menjalankan kapasitas mereka dalam menentukan dirinya sendiri. Menurut Taylor, kapasitas individu untuk menentukan dan mengembangkan dirinya sendiri justru dapat dijalankan hanya dalam konteks komunitas tertentu, dengan lingkungan sosial tertentu.

Michael Sandel adalah tokoh pertama yang membuka perdebatan seputar Komunitarianisme dengan Liberalisme pada sekitar tahun 1982 melalui karyanya yang berjudul Liberalisme and The Limits of Justice. Karya Michael Sandel ini merupakan kritik terhadap pemikiran John Rawls yang bersifat hipotetis. Tesis Rawls menegaskan bahwa masyarakat adalah baik apabila kondisi masyarakat adil. Agar kondisi masyarakat adil maka tatanan yang mengatur kehidupan masyarakat haruslah memuat dua prinsip, yaitu prinsip persamaan dan perbedaan yang dijalankan berdasarkan prinsip prioritas leksikal (Kymlicka, 2004: 71). Pertama, prinsip persamaan; tiap-tiap orang mempunyai hak yang sama atas keseluruhan sistem yang paling luas dari kebebasan-kebebasan dasar yang sama sesuai dengan kebebasan serupa bagi semua orang. Aturan prioritas pertama (prioritas kebebasan) yaitu prinsip-prinsip keadilan diurutkan dalam tertib leksikal dan karena itu kebebasan hanya dapat dibatasi demi kebebasan itu sendiri. Kedua, prinsip perbedaan; ketimpangan sosial dan ekonomi diatur sedemikian rupa sehingga keduanya: (a) memberikan keuntungan terbesar untuk yang paling tidak diuntungkan, dan (b) membuka posisi-posisi dan jabatan bagi semua di bawah kondisi-kondisi persamaan kesempatan yang fair. Aturan prioritas kedua yaitu prioritas keadilan atas efisiensi dan kesejahteraan. Prinsip keadilan yang kedua secara leksikal lebih penting daripada prinsip efisiensi dan prinsip memaksimalkan jumlah total keuntungan-keuntungan dan kesempatan yang fair lebih penting dari pada prinsip perbedaan.

\section{METODE}

Menggunakan metode pendekatan kualitatif pendekatan deskriptif. Untuk memperoleh data yang akurat tentunya diperlukan pula teknik pengumpulan data yang tepat, cepat, efisien dan ekonomis, sebagai berikut : (a) Wawancara yaitu Teknis penggalian data dan informasi secara lebih mendalam, dalam upaya pemahaman secara komprehensif dengan cara melalui tanya jawab secara langsung yang ditujukan secara lisan terhadap responden, yang berisikan sejumlah pertanyaan pokok yang telah dipersiapkan, dengan tujuan untuk mempermudah peneliti dalam melakukan wawancara, karena pertanyaan telah terstruktur sehingga mendapat hasil yang sesuai dengan yang diharapkan. (b) Observasi yaitu suatu teknik untuk mendapatkan data dari tempat kegiatan penelitian yang diamati, tetapi peneliti tidak ikut terlibat dalam kegiatan tersebut.

\section{HASIL DAN PEMBAHASAN}

Kecamata Rupat Utara memiliki potensi besar yang didapatkan dari kekayaan alam Indonesia, yaitu sektor perikanan hasil tangkapan dari laut. Secara geografis Rupat Utara berhadapan langsung dengan Selat Malaka, tentu kawasan perbatasan terluar Riau yang wilayahnya sangat strategis jika mampu dikembangkan dengan baik. Profesi nelayan merupakan suatu hal yang sudah dijalankan secara turun temurun, saat ini semakin banyak kajian menelisik bahwa masyarakat pesisir kurang berkembang dan terus dalam kondisi marjinal (Satria, 2015).

Asumsi masyarakat pesisir kurang berkembang dan terus dalam kondisi marjinal, merupakan konstruksi sosial yang menjadi problematis dalam masyarakat pesisir yang mata pencaharian sebagai nelayan. Alat tangkap nelayan yang digunakan pada umum nya menggunakan peralatan tradisional, dan sesuai dengan kemampuan ekonomi dari setiap nelayan. Situsi tersebut tidak sejalan dengan upaya Pemerintah Indonesia menciptakan pembangunan sumber daya kelautan dan perikanan harus menerapkan prinsip-prinsip pengelolaan sumber daya kelautan dan perikanan 
yang bertanggung jawab, berdaya saing, dan berkelanjutan.

Lokus penelitian ini dilaksanakan pada Desa Teluk Rhu, yang merupakan desa yang memiliki pesisir pantai yang memiliki rumah tangga nelayan berjumlah 321 orang. Lokus kedua pada Desa Tanjung Punak yang juga memiliki zonasi pesisir memiliki rumah tangga nelayan berjumlah 67 orang, dan lokus selanjutnya yang menjadi sentral dari Kecamatan Rupat Utara yaitu Desa Tanjung Medang, desa ini memiliki 326 orang nelayan dan juga menjadi lokasi tempat nelayan-nelayan melakukan transaksi jual beli ikan kepada pengepul yang berjumlah dua orang.

Setiap desa memili kelompok nelayan masing-masing, dan hampir semua komunitas nelayan tersebut tidak melaksanakan konsep komunitarian yang dipaparkan oleh Etzioni dalam jurnal (Schumaker, 2018), komunitas yang baik merupakan komunitas bersifat homogen yang mampu menampung kebutuhan dari setiap anggotanya, namun memiliki koneksi yang bersifat jangka panjang menguntungkan bagi komunitas dan anggotanya. Ilustrasi konsep tersebut dapat dituangkan dalam model maping berikut.

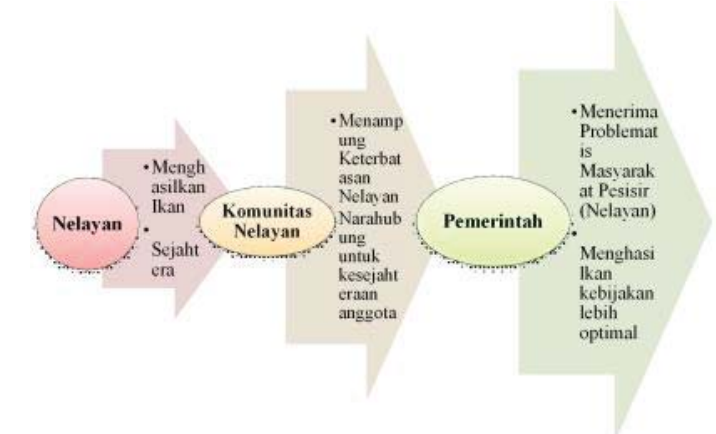

Gambar 1. Komunitarian oleh Etzioni

Gambar diatas menunjukan hirarki dari konsep komunitarian, yang dijadikan mind maping dalam penelitian ini. Dalam gambar tersebut peneliti mengilustrasikan kedudukan antara nalayan sebagai person dan keuntungan yang akan kembali kepada nelayan ketika komunitasnya dapat bertransformasi menjadi baik, sehingga menjadi penghubung kepada state atau pemerintah dalam upaya kesejahteraan bagi masyarakat yang selama ini diasumsikan se- bagai masyarakat marjinal.

Harapan yang dimunculkan dari komunitarian mampu memfasilitasi baik komunitas yang diisi oleh anggota yang bersifat homogen ataupun plural. Temuan di wilayah pesisir ternyata tidak mampu membantah kajian yang menyebutkan problematis wilayah pesisir tidak lepas dari kawasan marjinal, menjadi wilayah tapal batas Negara Indonesia dan Malaysia. Hampir seluruh komoditi perikanan yang dihasilkan oleh nelayan pesisir Rupat Utara menjual ikan-ikan segar yang siap dikirim ke Malaysia melalui Pengepul Ikan dengan sebutan oleh nelayan-nelayan setempat yaitu Pak Long.

Jika melihan hasil komoditi ekspor, maka dapat terlihat harga ikan-ikan dengan nilai yang sangat rendah. Konsumsi ikan pun lebih pasti terjual ketika ikan tersebut diekspor ke Negara Malaysia dari pada dikirim ke Dumai (dalam negeri). Peneliti mengambil sampel penelitian dari sejumlah nelayan tersebut di setiap desa Tanjung Medang, Teluk Rhu dan Tanjung Punak. Beberapa nelayan yang ditemui memilih tidak ikut dalam komunitas atau kelompok ketika menjual hasil tangkapan melaut, dengan kapal berjenis Pancung, dan jarring. Salah satu nelayan lain yang tidak ikut bergabung dengan kelompok, karena memang memilih sendiri dan menjual langsung ke toke atau pengepul ikan, jika alat tangkap rusak maka nelayan tersebut menyewa jarring atau peralatan melaut ke Toke atau Pengepul.

Sistem monopoli muncul dalam transaksi di masyarakat pesisir Rupat Utara, hanya terdapat dua tempat pengepul ikan. Sistem yang diberikan dapat berupa pemberian dana di awal sejumlah Rp. 20.000.000/3 tahun, maka nelayan-nelayan tersebut harus menyerahkan seluruh hasil tangkapan ikannya kepada pengepul yang telah memberikan dana dimuka. Hasil tangkapan ikan pun tidak semua ikan yang dapat dijual kepada pengepul, ikan-ikan dipilih yang layak untuk diekspor salah satunya adalah ikanikan yang tidak memiliki telur ikan. Hal tersebut dikarenakan untuk mengurangi kemungkinan pembusukan ikan ketika diperjalanan dari Tanjung Medang ke Malaka. Ikan-ikan hasil tangkapan yang tidak bisa diambil oleh 
pengepul itulah yang menjadi konsumsi dari masyarakat pesisir, lewat pengepul kecil harian, atau kedai-kedai yang menjual kebutuhan harian masyarakat.

Melihat dari sisi hadirnya Negara bagi kesejahteraan masyarakat pesisir, yang sebagian besar bekerja sebagai nelayan masih dirasa sangat minim. Dipahami bahwa Negara atau pemerintah membantu dalam upaya kesejahteraan baik berupa bantuan yang bersifat simultan maupun bersifat pendampingan serta pelatihan. Seperti yang dipaparkan oleh penelitian yang memaparkan bahwa program-program pelatihan yang diberikan memang terlaksana namun tidak memberikan pengaruh besar, karena nelayan-nelayan tersebut menganggap bukan hal tersebut yang mereka butuhkan (Purnama et al., 2016). Pekerjaan yang dianggap sebagai pekerjaan turun temurun, sehingga pendekatan dalam memberikan sosialisasi pun harus dapat membaca karakter dari nelayan-nelayan Kecamatan Rupat Utara. Hal ini terbukti bantuan fisik yang sangat baik telah diberikan, namun ternyata tidak memberikan manfaat karena keterbatasan yang dimiliki oleh nelayan sebelumnya tidak mampu terjawab.

Kominitas nelayan yang ada di Kecamatan Rupat Utara hanya bersifat dibentuk untuk memenuhi, kebutuhan nelayan-nelayan pada saat membuat permohonan bantuan. Pada goals yang dicapai hanya pada satu tujuan tentu tidak akan memberikan keberlanjutan, fakta lapangan menunjukan bahwa tidak semua nelayan merasa bergabung dalam kelompok itu akan menguntungkan karena pada akhirnya akan menjual kepada sejumlah toke sendiri-sendiri. Kartu tanda nelayan dan kelompok nelayan, esensinya ketika bergabung dalam kelompok nelayan memberikan keuntungan berupa bagi hasil dan kelompok mengupayakan kesejahteraan bagi masyarakat komunitas nelayan.

Pemaparan diatas menunjukan bahwa komunitas nelayan hanya dibentuk tanpa memiliki fungsi yang maksimal, hanya sekedar syaratk kelengkapan administrasi saja. Tidak ada kedudukan konsep komunitarian yang seperti dijabarkan oleh Etzioni, sehingga tidak memunculkan keberlanjutan. Ditambah tidak adanya pendampingan yang tepat sasaran kepada masyarakat nelayan, dan kelompokkelompok nelayan dari sejumlah kelompok nelayan terbentuk hanya satu yang memiliki izin resmi. Pengurusan izin akta notaris kepada kelompok nelayan yang dirasa cukup mahal, hanya dua kelompok yang memiliki izin pada Desa Teluk Rhu dan se Pulau Rupat gabungan Kecamatan Rupat dan Rupat Utara hanya satu desa pada tahun 2017 yang menerima bantuan dari Kabupaten Bengkalis, paparan dari UPT Dinas Perikanan Kecamatan Rupat Utara.

Tidak bersinerginya antara pemerintah dan komunitas nelayan serta nelayan-nelayan terlihat dari mulai tidak hadir maksimalnya tenaga pendamping kelompok nelayan. Serta pemahaman nelayan terhadap kepentingan ketika kelompok nelayan ini bersinergi pihak kecamatan secara administrative tidak memberikan posisinya, dalam mempertegas kebutuhan untuk kesejahteraan. Inovasi dalam memberikan penyuluhan dan sosialisasi yang tepat sasaran perlu dipertimbangkan oleh UPT Dinas Perikanan Kecamatan Rupat Utara, sebagai wakil dari pemerintah Kabupaten Bengkalis.

Penyederhanaan persepsi nelayan yang lebih memilih bantuan bersifat tunai ketimbang, penyuluhan. SDM Unggul dan Indonesia maju merupakan ide untuk merevolusi mental dari masyarakat pesisir. Peneliti menemukan sejumlah masyarakat dengan pola sederhana yang menganggap bahwa nelayan merupakan profesi turunan, yang pasti mereka dapatkan maka terkadang membenarkan bahwa alasan tidak perlu sekolah tinggi.

\section{SIMPULAN}

Kelompokbagisejumlahnelayanmerupakan persyaratan administrasi yang harus dibuat, untuk mengajuan bantuan. Memiliki kartu nelayan dan kelompok, sebagai langkah awal dan membentuk tanpa ada keberlanjutan karena tidak memaknai yang sebenarnya dari konsep komunitarian. Komunitas nelayan dianggap sangat banyak, karena memang sebagian besar dari mata pencaharian masyarakat setempat adalah nelayan. Kelompok atau komunitas hanya berupa simbol tanpa ada cita- 
cita bersama dalam meningkatkan taraf kesejahteraan. Hasilnya tidak ada aspirasi secara bottom up untuk menjadi narahubung kebijakan yang tepat, yang bisa diberikan kepada masyarakat pesisir.

\section{DAFTAR RUJUKAN}

Afrizal., 2016., Metode Penelitian Kuantitatif., Raja Grafindo Persada., Jakarta.

Aida, Ridha. 2005. Liberalisme dan Komunitarianisme: Konsep tentang Individu dan Komunitas. DEMOKRASI Vol. IV No. 2.

Amin Mudzakkir, ... Kembalinya Tradisi: Rasionalitas Dan Etika Komunitarian Alasdair Macintyre. Lembaga Ilmu Pengetahuan Indonesia - LIPI ISSN 2407-0556

Amrizal, Safrizal, Mahdi dan Junaidi, 2016. Pengembangan Usaha Perikanan Laut Berkelanjutan Berbasis Zona Penangkapan di Kabupaten Bengkalis, Disertasi Program Doktor Pascasarjana Universitas Andalas, Padang (tidak dipublikasikan) Badrudin, N.N Wiadnyana, B.Wibowo, 2005. Deep water exploratory bottom long lining In the waters of the Arafura Sea. Indonesian Fisheries Research journal, 11 (1) : pp 41-46.

Badrudin, Wudianto, N.N. Wiadnyana, dan S. Nurhakim, 2006. Deep sea fish resources Diversity and potential in the waters of western Sumatera of the Eastern Indian Ocean. Indonesian Fisheries Reseach journal. 12(2): pp 113-12.

Bailey and Brorsen (1989). Price Asymetry in Spatial Fee Cattle Markets.Western Journal of Agriculture Economics, Vol. 14. pp 246-252 .

Brill, R.W. et al, 1999. Horizontal Movements and depth Distribution of large adult Yellowfin tuna (Thunnus albacores) near the Hawaiian Islands, recorded using Ultrasonic telematry: Implications for the physiological ecology of pelagic fishes, Marine Biologi (133) pp $395-$ 408, Hawaii.

Dahuri, R., 2001. Potensi dan permasalahan pembangunan kawasan pesisir
Indonesia, Pusat kajian sumberdaya pesisir dan lautan IPB, Bogor.

Fauzi, A. dan S. Anna, 2005. Permodelan sumber daya perikanan dan kelautan untuk analisis kebijakan, Gramedia pustaka utama, Jakarta.

Ghofur, Abd. 2014. Problematika Pembangunan Pulau Terluardan Pemberdayaan Masyarakat di Kecamatan Rupat Utara Kabupaten Bengkalis. Jurnal Toleransi: Media Komunikasi Umat Beragama, 6 (1).

Indiahono, Dwianto., 2009., Perbandingan Administrasi Publik., Gava Media., Yogyakarta.

Kusumanegara, Solahuddin., 2010., Model dan Aktor dalam Proses Kebijakan Publik., Gava Media., Yogyakarta.

Nugroho, Riant., 2006., Kebijakan Publik untuk Negara-Negara Berkembang., PT. Elex Media Komputindo., Jakarta.

Otto G usti M adung, 2012. Relevansi perdebatan liberalismeversu komunitarisme untuk konteks Indonesia. $634 \mathrm{M}$ illah Vol. XI, No. 2, Februari 2012

Sartika, Ika. 2011. Evaluasi Kebijakan Pemberdayaan Nelayan. Jurnal Ilmu Administrasi Negara, 11 (2).

Parsons, Wayne., 2005., Public Policy Pengantar Teori dan Praktik Analisis Kebijakan., Kencana., Jakarta.

Tonny, Judiantono. 2011. Analisis Pola dan Estimasi Pergerakan Barang Sebagai Pertimbangan prioritas Pembangunan Jalan di Kabupaten Bengkalis Provinsi Riau. Jurnal Perencanaan Wilayah Kota Universitas Islam Bandung, 2 (11).

Purnama, C. R. A., Besar, B., Pelayanan, P., J1, S. B., Sosial, K., \& Sonosewu, N. (2016). Analisis Kebutuhan Pelayanan Sosial bagi Keluarga Nelayan Miskin. (1), 219-234.

Satria, A. (2015). Pengantar Sosiologi Masyarakat Pesisir. Buku Obor.

Schumaker, P. (2018). Amitai Etzioni: Communitarian Centrist and Principled Pluralist. Social Science Journal, 55(1), 4-5. https://doi.org/10.1016/j.soscij. 2018.02.004 